\title{
RELATION BETWEEN THE CONSTITUTIONAL COURT OF THE REPUBLIC OF INDONESIA AND THE LEGISLATORS ACCORDING TO THE 1945 CONSTITUTION OF THE REPUBLIC OF INDONESIA
}

\author{
Fajar Laksono, Sudarsono, Arief Hidayat, and Muchammad Ali Safaat \\ Universitas Brawijaya \\ fajarlaksono@yahoo.com
}

\begin{abstract}
This research aims to analyze and to describe the relation between the Constitutional Court of the Republic of Indonesia (CC) with the People Representatives' Council and the President of the Republic of Indonesia as legislators by looking on implementation of CC's decision through the legislation in the period 2004-2015. Using doctrinal research, it can be seen how the constitutional mandate in the CC's decision are implemented by the legislator through the legislation. The results are: (a) legal opinions of the CC's decision have a binding power; (b) a constitutional mandate in the legal opinion is intended as guidance for the legislators regarding what the 1945 Constitution requires; (c) directives to the legislator in the legal opinions should be implemented because it is the implementation of the principle of checks and balances according to the 1945 Constitution, (d) implementation of the CC's decisions through legislation does not have standard mechanism and does not become the priority of legislation, and (e) relation between the CC with the legislators can not be categorized in black and white in cooperative or confrontative, but shows ups and downs between cooperative and confrontative relations. Cooperative relations are realized when the constitutional mandate is formulated strongly so it is implemented by the legislator as the formula. Relationships tend to be cooperative in the implementation of the constitutional mandate of the decision, but not a priority of legislation. Meanwhile, the confrontative relations is seen from the constitutional mandate of the $\mathrm{CC}$ decisions which are not implemented.
\end{abstract}

Keywords: Relation, Constitutional Court, Legislator, Cooperative, Confrontative 


\section{INTRODUCTION}

\subsection{Background}

Legislation is a potential area of tension among key institutions that interact within it. Tensions arise especially after the Constitution 1945 of the State of the Republic of Indonesia (hereinafter referred to the Constitution 1945) adopts the idea of judicial review. ${ }^{1}$ According to the 1945 Constitution, legislation is the domain of the People Representatives' Council and the President ${ }^{2}$, while judicial review is the authority of the Constitutional Court of the Republic of Indonesia (CC). Judicial review is power to control legislation. ${ }^{3}$ That is, between legislation with judicial review intersect. In fact, judicial review is an important factor affecting legislation. ${ }^{4}$ Influence can be direct or indirect. ${ }^{5}$ On it tangency, tension can occur in the relationship of interacting institutions, namely the CC as an actor to judicial review with the People Representatives' Council and the President, as legislators.

Tensions are increasingly sharpening, because in a practice, the CC often gives constitutional orders to the legislator for legislative drafting. By Peter Paczolay, the constitutional order called a kind of 'mandamus' ${ }^{\text {, }}$, which is 'a constitutional mandate to legislate.7 Allan R. Brewer-Carias calls it "binding orders and directives to Legislator" or "instruction directives sent by CC to Legislator". ${ }^{8}$ Meanwhile, Georg S. Vanberg uses the term instructions on the drafting of laws. ${ }^{9}$ Referring to these terms, in this study, Peter Paczolay's said, we uses the term "constitutional mandate for the legislator".

\footnotetext{
1 "The 1945 Constitution of the Republic of Indonesia" (1945). Article 24C (1).

2 Ibid. Article 20.

3 John Ferejohn in Constitutional Review in the Global Context as quoted by Saldi Isra, "Purifikasi Proses Legislasi Melalui Pengujian Undang-Undang," Jurnal Legislasi Indonesia 7, no. 1 (2010): 214.

* Saldi Isra, Pergeseran Fungsi Legislasi, Menguatnya Model Legislasi Parlementer Dalam Sistem Presidensial Indonesia (Jakarta: Rajawali Press, 2010), 10

Volkansek, M.L. (2001), "Constitutional Court as Veto Players: Divorce and Decrees in Italy", European Jourbal of Political Research, 39. 347-372, as quotede by Michelle Santoni and Francesco Zucchini, "Legislative Output and the Constitutional Court in Italy," Kluwer Academic Publishers-Plenum Publishers 17, no. 3 (2006): 166.

${ }^{6}$ Latin for "We Order," a writ (more modernly called a "writ of mandate") which orders a public agency or governmental body to perform an act required by law when it has neglected or refused to do so. Writ of mandate or writ of mandamus is a court order to a government agency, including another court, to follow the law by correcting its prior actions or ceasing illegal acts, http://thelawdictionary.org/mandamus/. Accessed on 3 June, 2016.

7 Péter Paczolay, "Experience of the Execution of Constitutional Court's Decisions Declaring Legislative Omission In Hungary" (Execution of the Decisions of Constitutional Courts: A Cornerstone of the Process of Implementation of Constitutional Justice, Baku, 2008), 3.

8 Allan Brewer-Carias, "Constitutional Courts As Positive Legislators In Comparative Law," in General Report on XVIII International Congress of Comparative Law (International Academy of Comparative Law Washington, Washington, 2010), 145.

9 George Stephan Vanberg, The Politics of Constitutional Review: Constitutional Court and Parliament in Germany (New York: University of Rochester Rochester, 1999), 209.
} 
For example, Decision Number 012-016-019/PUU-IV/2006 dated December 19, 2006 in the examination of the existence of the Corruption Court in the Corruption Eradication Commission Law. The CC declared its constitutional mandate as follows,

...according to the Court, the legislator must immediately conduct the alignment of the Corruption Eradication Commission Act with the Constitution 1945 and form a law on the Corruption Court as a special court as the only system of corruption criminal justice, so the dualism of the corruption criminal justice system that has been Declared contrary to the 1945 Constitution as described above, may be omitted.... (bold by the author).

There are many other decisions with similar constitutional mandates. The mandate that can cause tension, especially because of the assumption that the CC takes over the authority of the Legislator in drafting the laws. Therefore, it is interesting and important to know the relation between the two institutions, especially from the perspective of checks and balances based on the 1945 Constitution.

Normatively, the CC decisions are final and binding to all state authorities." But in reality, there are problems in the implementation of it. Gunārs Kūtris said, the implementation of the decision is not the task of the $\mathrm{CC}^{12}$, but the domain of other state institutions. ${ }^{13}$ In addition, the presence of the $\mathrm{CC}$ is generally not politically desirable. ${ }^{14}$ Therefore, it is possible that the CC's decision is not implemented ${ }^{15}$ because of the relation of the two institutions. If that happens, it will be difficult to realize the constitutional legislation.

Regarding models of relations of two institutions, the term cooperative and confrontative proposed by Kathleen Barrett are used to describe the relationship

\footnotetext{
${ }_{10}$ Judicial Review Number 30 of 2002 on Commission for the Eradication of Criminal Acts of Corruption aganst the 1945 Constitution, No. 012-016-019/PUU-IV/2006 (2006). Decision No. 012-016-019/PUU-IV/2006.

${ }^{11}$ Ernst Benda, "Pelaksanaan Keputusan Mahkamah Konstitusi", Keputusan Mahkamah Konstitusi", in Norbert Eschborn, Tugas dan Tantangan Mahkamah Konstitusi Di Negara-Negara Transformasi dengan Contoh Indonesia (Jakarta: Konrad Adenaver Stiftung, 2005), 18.

${ }^{12}$ Gunārs Kūtris, "Authority of the Constitutional Court as the Preconditions of Execution of the Decisions," in Execution of The Decisions of Constitutional Courts: A Cornerstone of The Process of Implementation of Constitutional Justice (the Occasion of the 10th Anniversary of The Constitutional Court of Azerbaijan, Baku, 2008).

${ }_{13}$ Jongcheo Kim, "Some Problems with the Korean Constitutional Adjudication System," Journal of Korean Law 1 , no. 2 (2001): 32.

${ }^{14}$ Hans Kelsen, General Theory of Law and State (20th Century Legal Philosophy Series Vol. I) (Cambridge: Harvard University Press, 1949), 156.

${ }_{15}$ Isra, Pergeseran Fungsi Legislasi, Menguatnya Model Legislasi Parlementer Dalam Sistem Presidensial Indonesia, 301.
} 
of the constitutional court with legislators in a number of countries. ${ }^{16}$ Cooperative relations occur when both institutions work together to protect democracy and encourage the achievement of state goals. Meanwhile, confrontative relations occur when both institutions openly disagree with each other. ${ }^{17}$ Referring to that opinion, cooperative relationships are the most expected relations.

\subsection{Research Questions}

Based on above description, research questions are formulated as follow:

1. How is the philosophical, theoretical, and practical explanation of the legal consideration of the $\mathrm{CC}$ decision containing a constitutional mandate to legislators the framework of checks and balances principle according to the Constitution 1945? These questions are elaborated into the following 3 sub-questions:

a. Do the legal consideration of the CC's decision have binding power?

b. What is the purpose the CC to give a constitutional mandate to the legislators?

c. What about the constitutional mandate in the CC's decision in checks and balances perspective?

2. What is the relation between the $\mathrm{CC}$ and the legislators from the implementation of the CC's decision containing a constitutional mandate through legislation in the period of 2004-2015?

\subsection{Researchs Methods}

This research includes doctrinal law research with object or research target in the form of CC decision, law and other legal material. The result of legal research is not a new legal theory, but at least it is a new argument. ${ }^{18}$ The type of doctrinal law research is used to get a complete description of the legislation in the perspective of the CC's decision. On the other hand, this study is complemented by non-doctrinal legal research.

${ }^{16}$ Kathleen Barrett, "Constitutional Courts, Legislative Autonomy, and Democracy: What Price Rights?" (Georgia State University, 2014), 7-12.

${ }_{17}$ Barrett, 7-12.

${ }^{18}$ Peter Mahmud Marzuki, Penelitian Hukum (Surabaya: Kencana, 2005), 207. 
The object of the research is the CC decisions and the Act set in the period of 2004-2015. The CC decision is the decision of judicial review case whose legal opinions contain a constitutional mandate to legislator. Several approaches are used in this research, namely: (1) Philosophical Approach; (2) Statutory Approach; (3) Conceptual Approach; (4) Historical Approach; (5) Case Approach, and (6) Comparative Approach.

\section{RESULT AND DISCUSSION}

\subsection{Variant of Constitutional Mandate in the CC's Decision}

As stated above, the research object is the CC decision with legal consideration contains explicitly the constitutional mandate for the legislator in the drafting law. The number of decisions with final holdings or orders granted from 2004 to 2015 (as of December 31, 2015) are 203 decisions. Meanwhile, the total numbers of law established by the People Representatives' Council and the President from 2004 to the end of 2016 are 350 Act. Therefore, before answering the research question, it is important to present a decision with legal consideration containing a constitutional mandate with its variant. From 203 decisions during the period of 2004-2015, 29 decisions are qualified as research objects and grouped into 6 variants.

\subsubsection{Recommendations to Amendment or Establishment of New Act}

\begin{tabular}{|c|l|l|}
\hline 1 & $\begin{array}{l}\text { Decision Number o01- } \\
\text { 021-022/PUU-I/2003 }\end{array}$ & $\begin{array}{l}\text {...it is recommended that the legislators prepare } \\
\text { a new Electricity Bill in accordance with Article } \\
33 \text { of the } 1945 \text { Constitution. }\end{array}$ \\
\hline 2 & $\begin{array}{l}\text { Decision Number 005/ } \\
\text { PUU-IV/2006 }\end{array}$ & $\begin{array}{l}\text {...the Constitutional Court also recommends } \\
\text { to the People's Representative Council (DPR) } \\
\text { and the President to take immediate steps to } \\
\text { perfect the Judicial Commision Law. In fact, } \\
\text { DPR and the President also recommended to } \\
\text { make improvements that are integral... }\end{array}$ \\
\hline
\end{tabular}




\begin{tabular}{|l|l|l|}
\hline 3 & $\begin{array}{l}\text { Decision Number 4/PUU- } \\
\text { VII/2009 }\end{array}$ & $\begin{array}{l}\text {..the Court encourages the Legislators to be } \\
\text { more earnest to review all legislation so long } \\
\text { as it relates to the right of former convicted } \\
\text { Tailored to this Decision ... }\end{array}$ \\
\hline 4 & $\begin{array}{l}\text { Decision Number } 49 / \\
\text { PUU-IX/2011 }\end{array}$ & $\begin{array}{l}\text {...pending the amendment of the legislator, the } \\
\text { election of the Chairman and Vice Chairman } \\
\text { of the Constitutional Court shall be used by } \\
\text { the old rules... }\end{array}$ \\
\hline 5 & $\begin{array}{l}\text { Decision Number } 36 / \\
\text { PUU-X/2012 }\end{array}$ & $\begin{array}{l}\text {...momentum for Legislators to undertake a } \\
\text { rearrangement by promoting fair efficiency } \\
\text { and reducing the proliferation of government } \\
\text { organizations. }\end{array}$ \\
\hline 6 & $\begin{array}{l}\text { Decision Number } 85 / \\
\text { PUU-XI/2013 }\end{array}$ & $\begin{array}{l}\text {...while awaiting the establishment of a new Law } \\
\text { paying attention to the decision of the Court }\end{array}$ \\
\hline
\end{tabular}

\subsubsection{Providing an Alternative Norms to the Next Drafting Law}

\begin{tabular}{|l|l|l|}
\hline 1 & $\begin{array}{l}\text { Decision Number 072-073/ } \\
\text { PUU-II/2004 }\end{array}$ & $\begin{array}{l}\text {..legislator can make sure that the direct } \\
\text { Regional Head Election is an extension of the } \\
\text { notion of elections... } \\
\text {...but the legislator can also determine that the } \\
\text { direct Regional Head Election is not an election } \\
\text { in the formal sense mentioned in Article 22E } \\
\text { of the Constitution 1945. }\end{array}$ \\
\hline 2 & $\begin{array}{l}\text { Decision Number 49/PUU- } \\
\text { VIII/2010 }\end{array}$ & $\begin{array}{l}\text {..legislators should review the legislative review } \\
\text { immediately to provide certainty by choosing } \\
\text { one of the alternatives of the Attorney General's } \\
\text { term as follows. } \\
\text { a. based on the period of the Cabinet and/or the } \\
\text { term of office of the President appointing } \\
\text { him; } \\
\text { b. based on a fixed period of time without being } \\
\text { linked to the cabinet's political office; } \\
\text { c. by age or retirement age, or } \\
\text { d. based on the discretion of the President/ } \\
\text { official who appointed him }\end{array}$ \\
\hline
\end{tabular}




\subsubsection{Prohibition for the Legislator Including Certain Norms}

\begin{tabular}{|c|c|c|}
\hline 1 & $\begin{array}{l}\text { Decision Number } 013 / \\
\text { PUU-I/2003 }\end{array}$ & $\begin{array}{l}\text {...the prosecution of any form of crime must } \\
\text { be committed by law enforcement in a fair } \\
\text { and definite manner, not by creating a new } \\
\text { legal law through the formation of a "Perpu" } \\
\text { or a new law. }\end{array}$ \\
\hline 2 & $\begin{array}{l}\text { Decision Number 013-022/ } \\
\text { PUU-IV/2006 }\end{array}$ & $\begin{array}{l}\text {...in the draft of the Criminal Code which } \\
\text { is an effort to renew the Criminal Code of } \\
\text { the colonial inheritance must also no longer } \\
\text { contain articles of the same or similar content } \\
\text { to Article } 134 \text {, Article } 136 \text { bis, and Article } 137 \\
\text { of the Criminal Code... }\end{array}$ \\
\hline 3 & $\begin{array}{l}\text { Decision Number } 6 / \\
\text { PUU-V/2007 }\end{array}$ & $\begin{array}{l}\text {...the efforts to renew the Criminal Code } \\
\text { of the colonial legacy must also no longer } \\
\text { contain articles of the same contents. }\end{array}$ \\
\hline 4 & $\begin{array}{l}\text { Decision Number 97/ } \\
\text { PUU-XI/2013 }\end{array}$ & $\begin{array}{l}\text {...the authority of a state institution which is } \\
\text { limitatively determined by the Constitution } \\
1945 \text { can not be increased or decreased } \\
\text { by the Law or the Constitutional Court's } \\
\text { decision because it will take the role of the } \\
\text { Constitution. }\end{array}$ \\
\hline
\end{tabular}

2.1.4 The Requirement of the Legislator to contain specific Norms in the Next Drafting Law

\begin{tabular}{|c|l|l|}
\hline 1 & $\begin{array}{l}\text { Decision Number oo6/ / } \\
\text { PUU-IV/2006 }\end{array}$ & $\begin{array}{l}\text { famong others by realizing reconciliation in the } \\
\text { form of a legal policy (law) in harmony with } \\
\text { the } 1945 \text { Constitution and universally applicable } \\
\text { human rights instruments. }\end{array}$ \\
\hline 2 & $\begin{array}{l}\text { Decisions Number 11-14-21- } \\
126 \text { and } 136 / \text { PUU-VII/2009 }\end{array}$ & $\begin{array}{l}\text {..so that the legal entity law of education .... in } \\
\text { accordance with the Constitution } 1945 . . .\end{array}$ \\
\hline 3 & $\begin{array}{l}\text { Decision Number 147/ } \\
\text { PUU-VII/2009 }\end{array}$ & $\begin{array}{l}\text {...pending the formator s of the Act } \\
\text { accommodating ways apart from voting and } \\
\text { ticking... }\end{array}$ \\
\hline
\end{tabular}




\begin{tabular}{|c|c|c|}
\hline 4 & $\begin{array}{l}\text { Decision Number 115/ } \\
\text { PUU-VII/2009 }\end{array}$ & $\begin{array}{l}\text {...with this decision the legislators need to } \\
\text { take the initiative to conduct legislative review. } \\
\text {....the formator of the Law makes amendments } \\
\text { to the Law by containing provisions that are } \\
\text { more proportionate in accordance with the soul } \\
\text { of the decision of this Court }\end{array}$ \\
\hline 5 & $\begin{array}{l}\text { Decision Number 8/PUU- } \\
\text { VIII/2010 }\end{array}$ & $\begin{array}{l}\text {...In order to improve the Right to Inquiry Act } \\
\text { as a result of the unconstitutionality of Law No. } \\
6 / 1954 \text {, Legislators need to anticipate to form } \\
\text { Law as intended in Article 2oA Paragraph (4) } \\
\text { of the } 1945 \text { Constitution with due regard to Law } \\
\text { Number } 27 \text { Year } 2009 \text { which related to the rights } \\
\text { of Parliament and members of Parliament. }\end{array}$ \\
\hline 6 & $\begin{array}{l}\text { Decision Number 15/PUU- } \\
\text { IX/2011 }\end{array}$ & $\begin{array}{l}\text { Legislators should distinguish between the } \\
\text { procedures for forming or establishing a political } \\
\text { party with rules on the conditions imposed on } \\
\text { a political party in order for a political party to } \\
\text { be eligible, as well as the provisions governing } \\
\text { the legislature. }\end{array}$ \\
\hline 7 & $\begin{array}{l}\text { Decision Number 5/PUU- } \\
\text { VIII /2010 }\end{array}$ & $\begin{array}{l}\text {...the Court stated that there is a need for a } \\
\text { special law regulating wiretapping in general } \\
\text { to the tapping procedure for each authorized } \\
\text { institution }\end{array}$ \\
\hline 8 & $\begin{array}{l}\text { Decision Number 34/ } \\
\text { PUU-X/2012 }\end{array}$ & $\begin{array}{l}\text {... In the future, Legislators need to set the same } \\
\text { requirements for candidates of the Registrar of } \\
\text { the Supreme Court and the Constitutional Court }\end{array}$ \\
\hline 9 & $\begin{array}{l}\text { Decision Number 82/UU- } \\
\text { XII/2014 }\end{array}$ & $\begin{array}{l}\text {... a special treatment against women guaranteed } \\
\text { by the constitution that must be realized } \\
\text { concretely in the legal policy adopted by } \\
\text { legislator. }\end{array}$ \\
\hline 10 & $\begin{array}{l}\text { Decision Number 25/ } \\
\text { PUU-XII/2014 }\end{array}$ & $\begin{array}{l}\text {...the use of the Government Budget (Anggaran } \\
\text { Pendapatan dan Belanja Negara or APBN) for } \\
\text { operational costs of Financial Services Authority } \\
\text { (Otoritas Jasa Keuangan or OJK) shall contain } \\
\text { the time constraints which become the authority } \\
\text { of the Actors to assess them. }\end{array}$ \\
\hline
\end{tabular}




\begin{tabular}{|c|c|c|}
\hline 11 & $\begin{array}{l}\text { Decision Number 5/UU- } \\
\text { V/2007 }\end{array}$ & $\begin{array}{l}\text {...requires that the Local Government Law } \\
\text { adjust to the new developments that have been } \\
\text { made by legislators themselves that is by giving } \\
\text { the right to individuals to be able to run as } \\
\text { regional head and deputy head of the region } \\
\text { without having to go through a political party } \\
\text { or a coalition of political parties. } \\
\text {...to an entirely new material that must be } \\
\text { added in the law is the duty of the Legislator } \\
\text { to legislate it. }\end{array}$ \\
\hline 12 & $\begin{array}{l}\text { Decision Number 133/UU- } \\
\text { VII/2009 }\end{array}$ & $\begin{array}{l}\text {...the Law Number } 30 \text { Year } 2002 \text { should regulate } \\
\text { the procedure of filling temporary vacancy of } \\
\text { the Corruption Eradication Commission (Komisi } \\
\text { Pemberantasan Korupsi or KPK) leadership.... }\end{array}$ \\
\hline 13 & $\begin{array}{l}\text { Decision Number 58/ } \\
\text { PUU/XII/2014 }\end{array}$ & $\begin{array}{l}\text {...the distinction is regulated by legislator as a } \\
\text { positive legislator as long as the regulation of } \\
\text { the differentiation of electrical installations is } \\
\text { not contradictory to the Constitution. }\end{array}$ \\
\hline
\end{tabular}

2.1.5 The Requirement to Amendment or Establishment of New Act by Giving a Time Limit

\begin{tabular}{|l|l|l|}
\hline 1 & $\begin{array}{l}\text { Decision Number 54/PUU- } \\
\text { VI/2008 }\end{array}$ & $\begin{array}{l}\text {..in order to obtain tobacco excise } \\
\text { duty, it is necessary to amend the } \\
\text { provisions of Article 66A paragraph } \\
(1) \text { of Law Number } 39 \text { Year 2007. } \\
\ldots \text { that the allocation of tobacco excise taxes } \\
\text { for tobacco-producing provinces in the } \\
\text { APBN shall be fulfilled no later than the } \\
\text { 2010 Fiscal Year. }\end{array}$ \\
\hline 2 & $\begin{array}{l}\text { Decision Number 32/PUU- } \\
\text { XI/2013 }\end{array}$ & $\begin{array}{l}\text {..two years and six months after the Court's } \\
\text { decision is pronounced is sufficient time to } \\
\text { complete the Act. }\end{array}$ \\
\hline
\end{tabular}


2.1.6 The Necessity to Amendment or Establishment of New Act by Providing Time Constraints with Consequences if the Requirement is not Implemented

\begin{tabular}{|c|c|c|}
\hline 1 & $\begin{array}{l}\text { Decision Number 012-016- } \\
\text { o19/PUU-IV/2006 }\end{array}$ & $\begin{array}{l}\text {...legislator must immediately conduct alignment } \\
\text { of the Corruption Eradication Commission Act } \\
\text { with the Constitution } 1945 \text { and establish a law } \\
\text { on the Corruption Court ... } \\
\text {...if within three years can not be fulfilled by } \\
\text { the legislator, the provision of Article } 53 \text { of the } \\
\text { Corruption Eradication Commission Law by } \\
\text { itself, by law (van rechtswege), has no binding } \\
\text { legal force anymore. }\end{array}$ \\
\hline 2 & $\begin{array}{l}\text { Decision Number 13/PUU- } \\
\mathrm{VI} / 2008\end{array}$ & $\begin{array}{l}\text {...the Constitutional Court then needs to once } \\
\text { again remind legislator to no later than in the } \\
\text { APBN Law Fiscal Year } 2009 \text { must have fulfilled } \\
\text { its constitutional obligation to provide a budget } \\
\text { of at least } 20 \% \text { for education. }\end{array}$ \\
\hline
\end{tabular}

\subsection{Philosophical, Theoretical, and Practical Explanation on the Legal} Consideration with a Constitutional Mandate in Checks and Balances Perspective

This section describes an analysis of (1) the binding force of the legal consideration of the CC's decision; (2) the purpose of the CC to provide a constitutional mandate in the legal consideration of decision, and (3) CC's constitutional mandate to legislators in the perspective of checks and balances according to the 1945 Constitution.

\subsubsection{Binding Force of the Legal Consideration of the CC Decision}

The core question is which part of the CC decision is in effect binding, is it part of the decision only, or does it include the legal consideration section of the decision? There are two opinions about it. The first, a part which has the binding force as law and must be implemented is the decision. ${ }^{19}$ So, if the legal

${ }_{19}$ Refly Harun, An interview, 2017. 
consideration wants to have a binding force, constitutional mandate should be incorporated into the decision. Allan Brewer-Carias calls instructions to legislators in some cases being non-binding. The second opinion, which has binding strength, is that all statements in the decisions include legal consideration and the holding orders. ${ }^{20} \mathrm{~V}$. Guttler said, not only the statements of the binding decision, but also the legal opinion. ${ }^{21}$ I Dewa Gede Palguna stated that the legal consideration within constitutional interpretation should be said to be binding. If only the holding orders are binding, the decisions becomes lost context. ${ }^{22}$

Based on above opinions, the authors agree with the second one that the legal consideration of the CC decision have absolute binding force. In line with Ernst Benda $^{23}$, he said that almost all statements in the constitutional court decision are considered to have binding power, including obiter dicta. ${ }^{24}$ The argument, in the case of a CC ruling requires the implementation, in this case through the process of change or replacement of the Act, then the legal consideration should be referred to see what the holding orders.

There are two arguments that the legal consideration of the CC decision are binding. Judicially, regarding the decision, there are arrangements in Articles 45 to 49 of the CC Act (Act Number 24 Year 2003). In Article 47, it is stated that the CC decision obtains a binding legal force since the completion has been pronounced. In Article 48, it explains the content of the decision of the CC. ${ }^{25}$

\footnotetext{
${ }^{20}$ Although in other cases have mandatory characters. Allan Brewer-Carias classified it into two groups, namely (1) Non Binding Directives to the Legislator, and (2) Binding Orders and Directives to the Legislator. For example, the legal consideration of the German Constitutional Court and the Constitutional Court of Serbia are among others non-binding. A warning Decision is practiced in Germany, and is called "appellate decisions", which the Federal Constitutional Court of Germany Federal does not declare the unconstitutionality of a law, but rather gives "reprimands to legislators," whose contents are directed to the Legislator. Referrals can by asking legislators to make certain norms that are considered constitutional, by giving legislators a period of time to do so. After the time-out period, the provision will become unconstitutional and the Federal Constitutional Court of Germany must re-order the issue. The Constitutional Court of Serbia may provide opinions or indicate the need to adopt or revise the Act, as well as other relevant measures to be exercised in the protection of constitutionality and legality, which are used to exert pressure on the National Assembly to make laws compatible with constitutional or Fix existing rules but declared unconstitutional. Nevertheless, said Carias, the opinion of the Constitutional Court has no binding legal force, see Brewer-Carias, "Constitutional Courts As Positive Legislators In Comparative Law," 145.

${ }^{21} \mathrm{~V}$ Guttler, "Execution of Judgments of the Constitutional Court of the Czech Republic" (Czech, 2000), http://www. concourt.am/armenian/con_right/4-10-2000/Guttler.htm.

22 I Dewa Gede Palguna, An interview, 2017.

${ }_{23}$ Eschborn, Tugas Dan Tantangan Mahkamah Konstitusi Di Negara-Negara Transformasi Dengan Contoh Indonesia.

${ }_{24}$ Obiter dicta, according to Ernts Benda is an additional explanation or consideration that may be useful to understand the decision of nanum is not absolutely necessary for the conclusion of the constitutionality of the norm of the Act, ibid.

${ }_{25}$ Article 48 paragraph (2) states, Decision of the Constitutional Court shall contain: (a) the head of the decision reads: FOR THE SAKE OF JUSTICE UNDER THE ONE ALMIGHTY GOD; (b) the identity of the Party; (c) summary of the petition, consideration of the facts revealed in the trial; (d) the legal opinions on which the decisions are based; (e) the holding orders, (f) day, date of decision, name of Constitutional Justices, and Clerk.
} 
From the provisions of Article 47 and Article 48 paragraph (2), it can be seen that what is meant by the "decisions" of the CC which have legal binding is including the legal consideration. That is, it can be asserted that juridically, the legal consideration underlying the decision are to have binding power, together with the holding orders and other matters as referred in Article 48 paragraph (2).

Philosophically, the legal consideration of CC's decision are the basis for the CC to decide a judicial review case. Its enforcement must be carried out in an unobstructed manner, in the meaning of binding so that the law becomes orderly and the law is applied intactly. Any decisions decided by the CC must be accepted, respected, and implemented. Moreover, every petition always contains: If the CC decides otherwise, please decide it as fair (ex aquo et bono). It indicates that in the case of judicial review, each party has entrusted the CC to adjudicate its disputes, including to surrender all its decision. The consequence of such beliefs, the Applicants are obliged to obey any decision of the $\mathrm{CC}$, including if the CC has decided different from the parties. In that legal consideration, it is explained and affirmed about any decision by the $\mathrm{CC}$ in answering the application. Herein lies the strength of binding legal consideration because it requires the necessity of all parties to obey.

Furthermore, as the basis of the $\mathrm{CC}$ in deciding cases, the legal consideration is essentially the combination of 3 things, namely (1) utilization of legal knowledge, (2) authority of the CC, and (3) discretion of the Constitutional Justices. The legal consideration must be the result of the whole process of thinking Constitutional Justices using the method of constitutional interpretation that must be accountable according to law and jurisprudence. In addition, the legal consideration contains philosophy-based reasoning and legal theory, so that it can be understood and accepted to justice seekers in particular, and society at large. For this reason, the legal consideration of the decisions becomes an instrument for Constitutional Justices to fulfill obligations in plenary as interpreters of the Constitution. Based on these arguments, the legislator is bound to the constitutional mandate of the CC in legal consideration. 
So, in simple word, philosophical explanation of the binding force of the legal consideration can be stated in 3 matters, namely (i) the nature of legal consideration of the CC's decision are the basis of the reason of the Constitutional Court to arrive at the provisions concerning the constitutionality of the legal norms reviewed. The reason is the spirit of the decision; (2) the legal consideration of the CC's decision is constructed from the process of utilizing the legal knowledge of constitutional justices by using the logic of the 1945 Constitution; (iii) the legal consideration of the CC's decision is useful to provide a description of constitutional justice and constitutional thruth according to the 1945 Constitution related to the legal norms that have been reviewed.

Theoretically, the CC's decision is the professional respect of the constitutional judge (the most best legal expert) as the result of the dialectic of legal knowledge related to the norms of the Act being reviewed in the framework of judicial control under the doctrine of the unity of the constitution. Finally, in practice, legal explanations explain at what point the constitutional problem in the norm of the Act being reviewed. Legal consideration guides how decisions can be made, especially through legislation in the future. The legal consideration serves as a proof space to dismiss the notion that in deciding, the $\mathrm{CC}$ on relies on it discretion as the interpreter of the constitution.

\subsubsection{The Purpose of the CC to Give a Constitutional Mandate}

The doctrine of "the unity of the constitution", which means that the constitution must be understood as a unity, not only in the context of understanding the contents, but also when the constitution is to be implemented through the formation of the act. This is actually the basis for the emergence of a constitutional mandate in its decision to be implemented by Legislators.

The existence of the constitutional mandate, the CC actually explicitly says that it is dangerous for the Legislators when legislation is not in accordance with the Constitution in casu the CC decision. If such case remains to be done, potentially its Act will be submitted for re-examination to the CC. So, it depends 
on the Legislators, whether they want to legislate the Act as the CC's mandate or not. If not, then it is said, the risks and consequences are clear, when the Act does not conform to the $\mathrm{CC}$ decision, and then submitted a petition for judicial review of the Act, the CC shall just reviews, even invalidate it again on the basis of the previous relevant decision.

The variant of the constitutional mandate in the CC's decision, ranging from the soft character or formulated more vigorously, substantially depends on the urgency of the assessment of the $\mathrm{CC}$ at the time of deciding the case. That is, when selecting the formulation of the constitutional mandate in the consideration of the decision, the CC first looks at the urgency of making of the law relating to the case which is decided.

Through constitutional mandate, the CC has actually called on the Legislators to remove the unconstitutional nature of the act by changing the norms being reviewed. Furthermore, the CC's decision is on the same level as the 1945 Constitution where the 1945 Constitution is the source of the legitimacy of the Act being reviewed. The $\mathrm{CC}$ decision only redefines how norms and standards in the policies contained in the Act should be formulated. With the constitutional mandate, the Legislators are obliged to reformulate the prescriptions of norms in harmony with the values in the 1945 Constitution. That norms will be in line or not with the constitutional mandate of the CC. It can be seen whether the formation of the Act actually refers to the decision of the CC intended. The constitutional mandate in the legal consideration should be implemented by the Legislators if they want to produce an act with no constitutional problem. Even if it is ignored, then the consequences is the Act can be reviewed again. Most likely, the CC will declare it unconstitutional.

\subsubsection{Constitutional Mandate in Checks and Balances Perspective}

The principle of checks and balances according to the 1945 Constitution is based on the principle of limitation of power. Checks and balances keeps the government less powerful. So, what about the constitutional mandate in legal opinion in terms of the principle of checks and balances? 
Constitution as supreme law of the land must be upheld. Enforcement of the Constitution can done through 2 (two) terms, namely legislation by the People Representatives' Council and constitutional adjudication by the CC. Legislation plays an important role to clarify and detail the constitutional norms and regulate their implementation. Meanwhile, constitutional adjudication is important to "guard the constitutional values". Thus, the CC has the authority to ascertain whether the values of the 1945 Constitution are really enforced in practice. In that context, the CC has the authority to decide what the 1945 Constitution wants in its capacity as the sole intepreter of the constitution through constitutional interpretation methods. One of the basic premises of the 1945 Constitution as a written constitution is its capacity to "reach" the future, in the sense of its ability to adapt to issues that arise in the future. Such "range" territory is the authority of the CC. On that basis, the constitutional mandate to legislator in the legal consideration is an attempt of the CC to enforce the 1945 Constitution.

If related to the principle of checks and balances according to the 1945 Constitution as stated above, the flexibility of Legislators in carrying out the legislation function is limited by the interpretation of the CC in the decision. This is the consequence of the principle of supremacy of the constitutional in the context of a democratic constitutional state which places the 1945 Constitution as the supreme law with the $\mathrm{CC}$ as its guardian. Therefore, constitutional mandate in the legal consideration of the decision is not a form of confiscation of the authority to legislate an Act on behalf of constitutional interpretation. It is more appropriate to say that, through its decision, the CC precedes the Legislators in interpreting the Constitution.

From the above description, constitutional mandate in legal consideration of the decision contains the purpose of maintaining constitutional unity of the constitution, both in understanding the meaning of the contents of the Constitution, and when the Constitution is to be implemented, especially through legislation which becomes the authority of the Legislators as well as eliminating the unconstitutional nature of the Act with changes, or the establishment of a new act after the decision. 


\subsection{Relations of the Constitutional Court and the Legislators in the Implementation of the Decision of the Constitutional Court}

This section presents 2 (two) parts, namely (1) Pattern of Implementation of CC's Decision by the People Representatives' Council and the President as Legislators; which includes an analysis of the CC decision which has been, and has not been implemented by Legislators; and (2) Pattern of the Relation of the CC with People Representatives' Council and the President as Legislators in Implementation of CC Decision.

\subsubsection{Pattern of Implementation of the CC Decision by Legislators}

\subsubsection{CC's Decisions that have been Implemented through Legislation}

Referring to the entire law produced until 2016, from 29 decisions containing the constitutional mandate to the legislator, 11 decisions have been made through legislation as shown below.

\section{1) Decision Number oo1-021-022/PUU-I/2003}

The decision was implemented by the establishment of Law Number 30 Year 2009 on Electricity. The decision is binding in December 21, 2004 and only implemented in 2009, although the Electricity Draft Law entered Prolegnas Year 2006 which has been prepared since March 22, 2006. That is, the legislators take 5 (five) years to implement "suggestion" of CC, Commencing from the date the decision is binding until the enactment of Law Number 30 Year 2009 on 23 September 2009. The constitutional mandate of the CC uses the formula "recommended", then the legislators are free to meet or not meet the advice. From the aspect of substance, Law Number 30 Year 2009 on Electricity is the implementation of Decision Number 001-021-022 / PUU-I / 2003. Proven, Law Number 30 Year 2009 affirms the paradigm in the business of providing electricity no longer competition or competition that embraces the unbundling system as outlined in Article 1o paragraph (2) of Law Number 30 Year 2009 stating: The provision of electric power for the public interest as referred to in paragraph (1) can be integrated. 
The formulation is considered to enable the unbundling system. The proof, the norm of Article 10 paragraph (2) of Law Number 30 Year 2009 was filed as a judicial review case to the CC. Through decision Number 111 / PUUXIII / 2015 in December 14, 2016, the CC declares that Article 1o Paragraph (2) of Law Number 30 Year 2009 is contradictory to the 1945 Constitution and does not have binding legal force if the formula is defined as a justification of unbundling practices in business. The provision of electric power for the public interest in such a way as to eliminate state control in accordance with the principle of "controlled by the state". The last, legislators did not mention the Decision Number 001-021-022/PUU-I/2003 in Considerations as well as in the Elucidation of Law Number 30 Year 2009.

\section{2) Decision Number $072-073 / \mathrm{PUU}-\mathrm{II} / 2004$}

This decision was implemented by establishing Law Number 22 Year 2007 on the Organizer of General Election. It took more than 2 (two) years and 1 (one) month to implement the decision as from 22 March 2007 until the enactment of Law Number 22 Year 2007 on April 19, 2007. The constitutional mandate of the CC only covers the aspect of the substance, namely to provide an alternative choice to the Legislators to form a law which affirms that the election is determined to the election regime or not, then the matter of the timing of the implementation of the decision is not significant to be questioned because the $\mathrm{CC}$ does not time limit of completion of the Act. Legislators choose the alternative provided by the $\mathrm{CC}$, that is direct election is an extension of the definition of General Election..$^{26}$ The decision is not included in Law Number 22 of 2007. This implies the formation of the Act using an authentic legislative interpertation, whereas the interpretation has been provided by the $\mathrm{CC}$.

\section{3) Decision Number o12-016-019/PUU-IV/2006}

This decision shall be effected by formulating Law Number 46 of 2009 on the Corruption Court. The legislators implement 2 (two) constitutional

\footnotetext{
${ }^{26}$ In Article 1 paragraph (4) Law Number 22 of 2007 stated, General Election of Regional Head and Deputy Regional Head is the General Election to elect the regional head and deputy head of region directly in the Unitary State of the Republic of Indonesia based on Pancasila and the 1945 Constitution of the State of the Republic of Indonesia.
} 
mandates of the CC, namely (1) establishing the Law on Corruption Court; and (2) the Act shall be established within a maximum period of three years since Decision Number 012-016-019 / PUU-IV / 2006 was pronounced in a public plenary session. Law Number 46 of 2009 was established within a period of not more than 3 (three) years as stated in decision Number 012o16-019 / PUU-IV / 2006. The decision is valid since December 19, 2006 while Law Number 46 of 2009 was ratified in October 29, 2009. The decision listed in the Law Number 46 of 2009, it means the establishment of Law Number 46 of 2009 is based on the decision.

\section{4) Decision Number 005/PUU-IV/2006}

The decision is implemented by formulating Law Number 18 of 2011 concerning Amendment to the Judicial Commission Law. Although the constitutional mandate uses the "recommendation" formula, the Legislator do so by incorporating the amendment of the Judicial Commission Law into the Priority of Prolegnas 2008. We can say, Legislators need 5 years and 3 months to complete the Judicial Commission Law, which has since been decided in August 23, 2006 until the enactment of the Law on 19 November 2011. The constitutional mandate is not fully implemented, especially the harmonization and synchronization of other laws. Legislators do not include the decisions in the Act, although they are substantially in line with the Decision.

\section{5) Decision Number $5 / P U U-V / 2007$}

The decisions implemented by establishing Law Number 12 of 2008 by including rules on single candidates on the local election. It takes approximately 9 (nine) months for the legislators to implement the Decision as Law No. 12 of 2008 in April 28, 2008 is passed. The implementation period is not significant because the CC has not set the time limit. The decisions listed in Considering of the Law and the constitutional mandate is set out in Article 56 and Article 59 of Law Number 12 of 2008. 


\section{6) Decision Number 13/PUU-VI/20o8}

The decision was implemented with legislating the Law Number 41 of 2008 on State Budget in 2009. Legislators refers to the decision. It is seen that Legislators implement the decision due to a strong mandate accompanied by the ultimatum that the $\mathrm{CC}$ will declare the unconstitutionality of the entire Law on State Budget for Fiscal of 2009 when the education budget is set at less than $20 \%$.

\section{7) Decision Number 54/PUU-VI/20o8}

The decisions was implemented by establishing the Law Number 47 of 2009 on State Budget of 2010. Allocation of tobacco excise taxes for tobacco-producing provinces in APBN has been fulfilled starting APBN 2010 where NTB Province is set to earn Rp 109. 382.755.901. Legislator have not yet implemented a constitutional mandate to amend Article 66 Paragraph (1) of Law Number 39 of 2007 because the CC also does not impose time limits. Time limits in the constitutional mandate more effective makes the legislators implement the Decision.

\section{8) Decision Number 133/PUU-VII/2009}

The govenment regulation in lieu of laws (Perpu) was due to the void of the leadeship of the chief of the Corruption Eradication Commission (KPK). The formation of the govenment regulation in lieu of laws is not within the framework of implementing the decision. There is no inclusion of decision in the govenment regulation in lieu of laws. The regulation of filling the vacancy of the Leadership of the Corruption Eradication Commission is initiated by the President, not by the Legislator. So, the substance contained in Article 33 and Article 34 of the regulation Number 1 of 2015 is in line with the constitutional mandate of the CC.

\section{9) Decision Number 147/PUU-VII/20o9}

This decisions was implemented by establishing Law Number 1 of 2014 on the Election of Governors, Regents and Mayors. Legislators need more 
than 5 (five) years to carry out constitutional mandate of the CC considering that the CC also does not impose time limits on implementation. Legislators formulate the substance of the Decision in Article 85 paragraph (1) of Law Number 1 of 2014. The establishment of Law Number 1 of 2015 does not mention the decision as the basis for its formation.

\section{0) Decision Number $8 /$ PUU-VIII/2010}

The regulation on the right to inquiry has been regulated in Article 177 of Law Number 27 of 2009 concerning the People's Consultative Assembly (MPR), the People Representatives' Council (DPR), the Regional Representatives' Council (DPD), and the Regional People Representatives' Council (DPRD). The constitutional mandate of the People Representatives' Council's rights in decision is implemented through Law Number 17 of 2014 on the People's Consultative Assembly, the People Representatives' Council, the Regional Representatives' Council, and the Regional People Representatives' Council. Substantively, the provisions on the Rights of Parliament Questionnaire have been formulated by the Legislators in Articles 199 to 209 of Law Number 17 of 2014. The Decision is not not listed in the Law Number 17 of 2014.

\section{1) Decision Number 97/PUU-XI/2013}

Legislator implements the decision by establishing Law Number 8 of 2015 . Legislator require approximately 10 (ten) months to carry out the decision. Substantially, the decision is set forth in Article 157 and Article 158 of Law Number 8 of 2015. Decisions are not listed in Law Number 8 of 2015.

In addition to the above pattern, there are 3 (three) decisions that are implemented but the decisions are different from the 11 decision above. These 3 (three) decisions are:

\section{a. Decision Number 013/PUU-I/2003}

Until the end of 2016, there are no laws that apply a norm of law that should be general and abstract in a concrete event. According to the authors, it shows that the legislators have implemented the decision. 


\section{b. Decision Number 0o6/PUU-IV/2006}

Initially, efforts to form a law to replace the Truth and Reconciliation Commission (Komisi Kebenaran dan Rekonsiliasi) Act have been pursued. From 2008 to 2015, the Truth and Reconciliation Commission Act is included in the Draft of the Priority of Prolegnas 2015. However, in the development, efforts to resolve gross human rights violations of the past through reconciliation efforts are not done by legal policy. The President (in the capacity of the head of government) decided to form a new body, the Council of National Harmony (Dewan Kerukunan Nasional/DKN). Based on the authors, the decision has been made, but not by forming a new the Truth and Reconciliation Commission Act, but through the presidential decree on the establishment of the Council of National Harmony. ${ }^{27}$

\section{c. Decision Number 15/PUU-IX/2011}

Statement of the CC in order that legislator distinguishes between the procedure of forming or establishing a political party with the rules on the conditions imposed on a political party so that a political party can follow the general election, and the provisions governing the Regional People Representatives' Council, difficult to understand and of course difficult to implement. Legislators have arranged all three in their respective laws. The constitutional mandate is aimed at assessing the provision of Article 51 Paragraph (1) of Law 2 of 2011 which confuses three things, namely (i) the procedures for the establishment or establishment of political parties; (ii) the rules on the conditions imposed on a political party in order for a political party to be eligible; and (iii) the institutional provisions of the Regional People Representatives' Council. Since the arrangement of 3 things already exists in a separate law, the implementation of the mandate is not seen from whether the Legislators make amendment or drafting new laws, but viewed from the presence or absence of norms

${ }^{27}$ Prima Gumilang, "Perpres Pembentukan Dewan Kerukunan Tinggal Diteken Jokowi," Cnnindonesia.Com, 2017, https://www.cnnindonesia.com/nasional/20170309182222-20-199074/perpres-pembentukan-dewan-kerukunantinggal-diteken-jokowi/. 
that confuse the above 3 things. Until 2016, there is no rule of law that confuses the arrangement of all 3 above. For this reason, according to me, legislators have implemented the decision.

\subsubsection{CC's Decision which have not been Implemented by the Legislators}

Until the end of 2016, there are 13 decisions with constitutional mandates that have not been implemented. The decisions are presented in the following table.

CC's Decision which have not been Implemented by Legislators

\begin{tabular}{|c|l|c|}
\hline No. & \multicolumn{1}{|c|}{ DECISION } & YEAR \\
\hline 1 & $\begin{array}{l}\text { Decision Number 013-022/PUU-IV/2006 in the judicial review of } \\
\text { the Penal Code Law }\end{array}$ & 2006 \\
\hline 2 & $\begin{array}{l}\text { Decision Number 6/PUU-V/2007 in the judicial review of the } \\
\text { Penal Code Law }\end{array}$ & 2007 \\
\hline 3 & $\begin{array}{l}\text { Decision Number 4/PUU-VII/2009 in the judicial review of } \\
\text { norms of imprisonment for public officials in the Election Law } \\
\text { and Law on the Establishment of Laws and Regulations }\end{array}$ & 2009 \\
\hline 4 & $\begin{array}{l}\text { Decision Number 11-14-21-126 and 136/PUU-VII/2009 in the } \\
\text { judicial review of the Law on Education Law Entity }\end{array}$ & 2010 \\
\hline 5 & $\begin{array}{l}\text { Decision Number 115/PUU-VII/2009 in the judidial review of the } \\
\text { Manpower Law }\end{array}$ & 2010 \\
\hline 6 & $\begin{array}{l}\text { Decision Number 49/PUU-VIII/2010 in the limit of term of } \\
\text { Attorney General in the Attorney Law }\end{array}$ & 2010 \\
\hline 7 & $\begin{array}{l}\text { Decision Number 49/PUU-IX/2011 in the judicial review of the } \\
\text { Constitutional Court Law }\end{array}$ & 2011 \\
\hline 8 & $\begin{array}{l}\text { Decision Number 5/PUU-IX/2011 in the regulation concerning } \\
\text { interception in the Information and Electronic Transaction Law }\end{array}$ & 2011 \\
\hline 9 & $\begin{array}{l}\text { Decision Number 36/PUU-X/2012 (Law Number 22 Year 2001: BP } \\
\text { Migas) }\end{array}$ & 2012 \\
\hline 10 & $\begin{array}{l}\text { Decision Number 34/PUU-X/2012 in the judicial review of the } \\
\text { Constitutional Court Law on Pension Age for the Court's Clerk }\end{array}$ \\
\hline
\end{tabular}


Relation between the Constitutional Court of the Republic of Indonesia and the Legislators according to the 1945

Constitution of the Republic of Indonesia

\begin{tabular}{|c|l|c|}
\hline 11 & $\begin{array}{l}\text { Decision Number 85/PUU-XI/2013 concerning the complete } \\
\text { cancellation of the Water Resources Law }\end{array}$ & 2015 \\
\hline 12 & $\begin{array}{l}\text { Decision Number 25/PUU-XII/2014 in the judidial review of the } \\
\text { Financial Services Authority Act }\end{array}$ & 2015 \\
\hline 13 & $\begin{array}{l}\text { Decision Number 58/PUU-XII/ 2014 in the judicial review of the } \\
\text { Electricity Law }\end{array}$ & 2015 \\
\hline
\end{tabular}

The matters that make Legislators have not fulfilled the constitutional mandate of the CC decision are (1) the law that is ordered to be changed or perfected has not yet been discussed ${ }^{28}$; (2) Legislators have not fulfilled the constitutional mandate of the CC because its implementation will include the amendment of many laws; ${ }^{29}$ (3) The decision of the $\mathrm{CC}$ has been implemented, but not through changes or the formation of law, but by Government Regulation;30 (4) Legislator thinks that legislative review is not urgent because the decision of the CC which is self-implementing is considered to have solved the constitutional problem. ${ }^{31}$

\subsubsection{Decisions Not Implemented by Legistors}

There are 2 decisions that are not implemented by Legislators shown in the table below.

\footnotetext{
${ }^{28}$ As an example of whether or not the constitutional mandate of Decision Number 013-022/PUU-IV/2006 and Decision Number 6/PUU-V/2007 will be seen when the Draft of the Criminal Code Bill is being discussed. Likewise, the draft amendment of the Constitutional Court which is currently in the process of amendment can be attributed to Decision Number 49/PUU-IX/2011 dan Decision Number 34/PUU-X/2012 (judicial review of the CC Law). Similarly, the Draft Water Resources Act associated with Decision Number 85/PUU-XI/2013 which is currently in the process of legislation.

$29 \mathrm{It}$ is found in Decision Number 4/PUU-VII/2009 reviewing the Election Law. A review of a number of laws that contain the norms of a condition is not criminalized to a public official not an easy matter, although it must be done. Likewise, Decision Number 5/PUU-IX/2011 Concerning the testing of eavesdropping rules in the Information and Electronic Transaction Law. There are many laws that must be changed to unify the wiretapping rules in a single law.

30 This is found in Decision Number 11-14-21-126 and 136/PUU-VII/2009 In the judicial review of the Law on Education Law. Government Regulation Number 66 Year 2010 Is a consequence of the mandate of the Constitutional Court's decision when the Constitutional Court provides guidelines if the regulation concerning education legal entity is regulated by Law.

${ }^{31}$ This is found in Decision Number 49/PUU-VIII/2010 regarding judicial review of the term of Attorney General in the Attorney Law. Included in this case Decision Number 115/PUU-VII/2009 In the judicial review of the Manpower Act. Similarly, Decision Number 36/PUU-X/2012 Regarding the examination of the existence of BP Migas in Law Number 22 Year 2001, Decision Number 25/PUU-XII / 2014 in the judidial review of the Financial Services Authority Law, and Decision Number 58/PUU-XII/2014 in the judidial review of the Electricity Law until 2016, there is no intention to make any changes or use of the Law.
} 
CC's Decisions which have not been Implemented by Legislators

\begin{tabular}{|c|l|c|l|}
\hline NO. & \multicolumn{1}{|c|}{ DECISION } & YEAR & \multicolumn{1}{|c|}{ INFORMATION } \\
\hline 1 & $\begin{array}{l}\text { Decision Number 82/PUU-XII/2014 } \\
\text { regarding the representation of } \\
\text { women in filling the leadership of } \\
\text { DPR }\end{array}$ & 2014 & $\begin{array}{l}\text { Law Number 42 Year 2014 } \\
\text { which is a revision of the Act, } \\
\text { done not in line with the CC } \\
\text { Decision. }\end{array}$ \\
\hline 2 & $\begin{array}{l}\text { Decision Number 32/PUU-XI/2013 } \\
\text { concerning regulation of insurance } \\
\text { based on Mutual }\end{array}$ & 2014 & $\begin{array}{l}\text { The deadline for the legislate } \\
\text { of the law is determined to be } \\
\text { a maximum of 2 years and 6 } \\
\text { months after the pronounced } \\
\text { decision has passed }\end{array}$ \\
\hline
\end{tabular}

In Law Number 42 of 2014, there is not any provision for the removal of the constitutional mandate of Decision Number 82/PUU-XII/2014. The regulation on filling the leadership of the Regional People Representatives' Council's fittings, whether Commission, Legislation Agency, Budget Agency, Inter-Parliamentary Cooperation Board, the Honorary Court of Parliement, or Household Affairs Agency, does not mention the matter of female representation according to the balance of the number of members of each fraction. If the priority of women representation according to the balance of the number of members of each fraction is regulated in the DPR regulations on the order, it is clearly not appropriate. Because, stated in the decision, "the legal policy taken by the legislator". Legislators are the People Representatives' Council and the President. It is true that the revisions have been made, but the content material is inconsistent with the decision of the CC. Similarly, the 16 Act generated until the end of 2016, there is not any law on Insurance Business in the form of mutual. Even if in the coming years the law is established, the law has exceeded the time limit specified in the constitutional mandate of the CC. The legislators do not implement this decision because the constitutional mandate does not impose deadlines and consequences if the constitutional mandate is not implemented. Therefore, the Legislators tend to prefer to choose the option to implement or not the decision. There is not any effect that will be accepted by the the legislators. 
Based on all of the above arguments, mainly answering the second research question, whether against decisions that have been, neither, nor have been implemented, the authors draw the conclusion into the following matter: (a) there are not any standardized patterns in implementing the constitutional mandate in the legal opinion of the CC decision; (b) in term of time, legislators do not prioritize the implementation of decisions. It is also determined by the choice of formulation of the mandate. If it is compulsory, legislators will implement exactly as the mandate sentences; and (c) legislators implement the CC's decision through 2 patterns, namely: (a) affirming into the act; and (b) taking the substance of the constitutional mandate, without listed it in the act.

\subsubsection{Pattern of Relation of CC and the Legislators in Implementation of CC's Decision}

Regarding to 14 CC's decisions, it can be seen that, (i) only in 2 decisions, legislators implement in accordance with the constitutional mandate; and (ii) legislators implement the constitutional mandate in the form of a prohibition for legislators to contain certain norms as outlined in 4 decisions. Both of these indicate cooperative relations. The CC provides guidance for legislation products which are no longer problematic and legislators carry out the mandate. However, cooperative relationships are not fully realized in other decisions. In a decision with a constitutional mandate in the form of a requirement to contain specific norms in the formulation of new act, without time constraints, and without mentioning the consequences if the requirement is not exercised, the legislators do not position it as a priority of legislation. If it is implemented, legislators are often reluctant to call the CC's decision as the legislative basis. Similarly, with 13 decisions that have not been implemented, cooperative relationships can not be realized. For example, since the implementation of the constitutional mandate of the CC decision will include the amendment of many laws, legislators do not position it as a priority of legislation. Whereas precisely because the constitutional problem exists in many laws, legislation should be hastened to eliminate the problem. This also means that legislator perpetuate judicial legislation, a practice 
that is not politically desired by legislators themselves. Meanwhile, against 2 decisions are not implemented, clearly proves confrontative relations. Although its constitutional mandate is so clear, but legislators ignore it.

If simplified, above dynamics are influenced by several factors. First, the CC needs to have more confidence to affirm its binding constitutional mandate. Although the $\mathrm{CC}$ must remain cautious in formulating a constitutional mandate, the CC should keep in mind that all statements in the decision have binding power. The CC may not allow itself to give a constitutional mandate that has only a persuasive effect. It is imperative that the constitutional mandate in legal opinions has consequences if the mandate is delayed or failed to be implemented by the legislator. The consequences are legitimate coercive instruments to ensure that decisions are made.

Second, because legal opinions have binding power, so in formulating the constitutional mandate, the CC must really ensure its legal opinions always in the framework of interpretation of the Constitution which is easily understood by legislator. The CC needs to pay attention to several signs (a) consider the possibility and clarity for legislator in implementing the decision; (b) to set a time limit when the decision should be implement; and (c) include consequences if the constitutional mandate is delayed or is not implemented.

Third, the constitutional mandate of the CC is in accordance with the principle of checks and balances according to the 1945 Constitution. The constitutional mandate is not an intervention, but implementation function of the CC as the sole interpreter of the constitution.

Fourth, on implementing of the CC decision, self respect should not be dependable. For this reason, in addition to the factors of the CC and the legislator, the rule of law is required to provide assurance. Moreover, cooperative relations can also be realized. So in this case, law must be above politics to get its justification.

Without cooperative relations, the existence of the CC and Legislator, as an important substance in the design of the Constitution 1945, will always be less than 
optimal in implementing the Constitution 1945 values in a responsible manner. For the CC, in the name of the Constitution 1945, the principle of constitutional supremacy which establishes it as the sole interpreter of the constitution shall not contribute to impede cooperative relations. Similarly, the People Representatives' Council and the President as legislators, the parliamentary supremacy paradigm should be abandoned. The CC is not a 'little parliament' that can against the existence and the authority of legislators.

In order to realize cooperative relationships, we needs to reaffirm the need for new law that became the legal basis of obligations and how the decision of the CC is implemented. Therefore, Legislators need not be resistant to establishing it. The reason is (i) the purpose of new law is to strengthen the supremacy constitution, and (ii) relation of the CC and legislators realized by the commitment of the achievement of vision and national goals as stated in Paragraph IV Preamble of the Constitution 1945.

\section{CONCLUSION AND SUGGESTION}

\subsection{Conclusion}

1. Philosophically, theoretically, and practically explanation of CC's decision containing constitutional mandate to Legislators in the framework of checks and balances are as follows, 1) legal consideration of the CC's decision are absolute binding because it contains (i) the basis of the CC to declare the "constitutional" or "unconstitutional" norms being reviewed; (ii) an explanation at which point a constitutional problem occurs; and (iii) an explanation of how decisions should be implemented; 2) through constitutional mandate, the $\mathrm{CC}$ aims to provide guidance to legislators regarding what is the 1945 Constitution desire; 3 ) the constitutional mandate by the CC is not intervention to the authority of legislators, but it is actually implementation of the principle of checks and balances according to the 1945 Constitution; 
2. Relation between the $C C$ and legislators from the implementation of the CC decision shows ups and downs between cooperative and confrontative relations. Cooperative relations are realized when the constitutional mandate is formulated strongly when legislators carry out the mandate as it should be. Relationships tend to be cooperative as seen from the implementation of the constitutional mandate of the decisions, but do not position it into the priority of legislation. Meanwhile, confrontative relation is seen from the non-implementation of the CC's decision on (i) the allocation rule of women who holds the chair of the People Representatives' Council (DPR), and its equipment in the judicial review of Act on People's Consultative Assembly (MPR), the People Representatives' Council (DPR), the Regional Representatives' Council (DPD), and the Regional People Representatives' Council (DPRD); and (ii) for insurance to be confirmed through law as a mutual effort in the examination of the Insurance Law.

\subsection{Suggestion}

1. For the CC, because the CC decision have a broad spectrum, so formulation of the constitutional mandate in the decision needs to pay attention to the signs of (a) formulated in the context of constitutional interpretation and minimizing additional explanation (obiter dicta); (b) facilitate legislators to implement the decision; (c) imposes a time limit on implementation; and (d) inclusion of consequences if the constitutional mandate is delayed or not implemented.

2. For legislators, when discussing and approving in making law process, which is required not only by the majority vote for the purpose and understanding of the act, but also the majority vote for its constitutionality aspects, including ensuring whether the act has referred to the constitutional mandate of the $\mathrm{CC}$;

3. Referring to the expereience and practice in several countries, the steps to realize the cooperative relations of the $\mathrm{CC}$ and legislators is to create rules 
on the implementation of the CC decision, in the Constitution 1945, in the act, and the CC's decision.

4. The legal rules regarding the implementation of the CC's decision is important to realize a lasting cooperative relationships. Therefore, the CC and legislator must be aware of the nature and meaning that the ultimate goal of the exercise of their respective powers is the same, namely enforcing the 1945 Constitution.

\section{REFERENCE}

Barrett, Kathleen. "Constitutional Courts, Legislative Autonomy, and Democracy: What Price Rights?" Dissertation, Georgia State University, 2014.

Brewer-Carias, Allan. "Constitutional Courts As Positive Legislators In Comparative Law." In General Report on XVIII International Congress of Comparative Law. Washington, 2010.

Eschborn, Norbert. Tugas Dan Tantangan Mahkamah Konstitusi Di NegaraNegara Transformasi Dengan Contoh Indonesia. Jakarta: Konrad Adenauer Stiftung, 2005.

Gumilang, Prima. "Perpres Pembentukan Dewan Kerukunan Tinggal Diteken Jokowi." Cnnindonesia.Com. 2017. https://www.cnnindonesia.com/ nasional/20170309182222-20-199074/perpres-pembentukan-dewan-kerukunantinggal-diteken-jokowi/.

Guttler, V. "Execution of Judgments of the Constitutional Court of the Czech Republic." Czech, 200o. http://www.concourt.am/armenian/con_ right/4-10-200o/Guttler.htm.

Harun, Refly. An interview, 2017.

Isra, Saldi. Pergeseran Fungsi Legislasi, Menguatnya Model Legislasi Parlementer Dalam Sistem Presidensial Indonesia. Jakarta: Rajawali Press, 2010.

_—_. "Purifikasi Proses Legislasi Melalui Pengujian Undang-Undang." Jurnal Legislasi Indonesia 7, no. 1 (2010).

Judicial Review Number 30 of 2002 on Commission for the Eradication of Criminal Acts of Corruption aganst the 1945 Constitution, No. 012-016-019/ PUU-IV/2006 (2006).

Kelsen, Hans. General Theory of Law and State (2oth Century Legal Philosophy Series Vol. I). Cambridge: Harvard University Press, 1949. 
Kim, Jongcheo. "Some Problems with the Korean Constitutional Adjudication System." Journal of Korean Law 1, no. 2 (2001).

Kūtris, Gunārs. "Authority of the Constitutional Court as the Preconditions of Execution of the Decisions." In Execution of The Decisions of Constitutional Courts: A Cornerstone of The Process of Implementation of Constitutional Justice. Baku, 2008.

Marzuki, Peter Mahmud. Penelitian Hukum. Surabaya: Kencana, 2005.

Paczolay, Péter. "Experience of the Execution of Constitutional Court's Decisions Declaring Legislative Omission In Hungary." Baku, 2008.

Palguna, I Dewa Gede. An interview, 2017.

Santoni, Michelle, and Francesco Zucchini. "Legislative Output and the Constitutional Court in Italy." Kluwer Academic Publishers-Plenum Publishers 17, no. 3 (2006): 165-87.

The 1945 Constitution of the Republic of Indonesia (1945).

Vanberg, George Stephan. The Politics of Constitutional Review: Constitutional Court and Parliament in Germany. New York: University of Rochester Rochester, 1999. 